\title{
Rapidly Changing Dynamics of Urbanization in China; Escalating Regional Inequalities and Urban Management Problems
}

\author{
Ghulam Akhmat (Corresponding author) \\ School of Architecture and Urban Planning, HUST University, Wuhan, China \\ E-mail: ahmad_choudary@hotmail.com \\ Yu Bochun \\ School of Architecture and Urban Planning, HUST University, Wuhan, China \\ E-mail: yubochun@163.com
}

\begin{abstract}
A multitude of factors; tremendous urbanization after the economic reforms of 1978, particularly the open door policy, foreign direct investment, industrialization in the last two decades and globalization have shaken the dynamics of Chinese cityscape, especially in the coastal areas. Level of urbanization is expected to reach 50 percent of the total population, which was less than 20 percent in 1978; creating urban management problems and inter-regional inequality in china, which is the focus of this study. Patterns of regional inequality across china's macro regions differ from that across the provinces; within provinces and inequalities across regions also differ from that across the counties, which requires a multiscale approach to address these problems. Factors of regional development in china differ considerably from Western countries, and theories of regional inequality remain less sensitive to the transition economies like China, which are undergoing dramatic restructuring. This study focused on the dramatic changes which China has been experiencing since the launch of economic reforms in 1978, which emphasizes decentralization, marketization, and globalization consequently, global and local forces have emerged as major forces shaping China's regional inequalities and urban management problems.
\end{abstract}

Keywords: Urbanization, Regional inequality in China

\section{Introduction}

Urbanization, referring to the expansion in the proportion of a population living in urban areas, is one of the major social transformations sweeping the globe. Now more than half the world's population is living in urban areas, and by the year 2050, 70 percent will be city dwellers, with cities and towns in Asia and Africa registering the biggest growth. Urban population is anticipated to grow on an average $2.3 \%$ per year in the developing world between 2000 and 2030 (Brockherhoff, 2000) (United Nations, 2004). China has the largest urban population in the world but a comparatively low urbanization level, approximately $10 \%$ lower than the world average and $30 \%$ lower than more developed regions (United Nations, 2004). Urban transformation in China is neither a historical nor historically deterministic; it is both a local and a global phenomenon (Abramson, 2006).

By the year 2000, China found itself with not only one of the highest rates of economic growth but also one of the highest degrees of rural-urban income inequality in the world, consequently widening the spectrum of regional inequalities (Yang , 2002); a new phenomenon for China in the last half century. From the Mao era till 1986, inequality across major regions (as measured by the coefficient of variation of per-capita real gross domestic product) trended downward, but a sharp rise was observed in the decade of the 1990s. Prior to the reform and opening, the Chinese state had controlled almost all resource allocations such as capital and land.

The way urbanization is managed and administered has a direct bearing on its ability to support economic development, social development, health systems and mitigate poverty. There is scarcity of resources and societies are usually divided along race, class, gender, and ideological lines. So community planners and urban managers have to take the path of sustainable development and establish socially just urban places. Presence of many new and outside factors in urban development - such as FDI, private investment, temporary residents and transient populations require an explicit vision in urban management (Belton Fleisher et al, 2009). This article gives an overview of escalating regional inequalities and urban management problems, due to rapidly changing dynamics of urbanization in China.

\section{City Typology}

In their effort to sort out the complexities of the cities in different geographic, historical, economic and cultural settings, scholars have constructed various typologies to categorize cities, for instance preindustrial city, colonial city, capitalist city, neoliberal city, post-modern city, Third World city, socialist city and post-socialist city, etc. (Ma, 2002). This useful mode of analysis highlights most salient features of a city existing in a particular period of time. Here we give a comparison of socialist city that existed during the first three decades of Socialism in China (1949-1978) and the post-socialist city that has emerged after the 1978 reforms, with a special emphasis on social and regional inequalities and urban management problems: 


\subsection{Socialist Cityscape in China}

Chinese cities under state socialism were seats of administration that anchored the state's territorial power, where all the urban structures echoed the glory of socialism. City was also the heart of the core program of state socialism i.e. industrialization, so it always contained distinct sociospatial attributes, which include: 1) City consisted of dual centres at different places, one political and the other commercial. Most magnificent buildings in the political centre were occupied by the city government, projecting the greatness of socialism. By contrast, the commercial centre, often some distance away, was much less impressive where state stores offered limited variety of consumer goods; 2) Industries were set up in various parts of the city and as the land was free, many of the urban industries occupied large areas of land. Absence of an open land market created abrupt land use patterns; and 3) Income was never a factor sorting socialist urban space. Housing size and quality could vary by family size, employment rank and the prestige.

Viewed as a whole, these spatial attributes were directly or indirectly related to the city as the locale for socialist industrial development. The city was not a well-integrated independent economic entity with vibrant economic activities of its own because all industrial units were vertically integrated and controlled by their superior administrative units, typically central ministries. Visually it was clean but drab, orderly but dull, and standardized in urban design but monotonous in building style. Socially, the city was disciplined but humdrum, safe but lacklustre and with very few social facilities and events to enliven the restrained urban sensation. Personal income was strictly controlled by the state, which helped curtail social and economic stratification and income inequalities (Ma and $\mathrm{Wu}, 2005$ ).

\subsection{Post Socialist Cityscape in China}

As a consequence of multitude of factors; tremendous urbanization after the economic reforms of 1978, particularly the open door policy, foreign direct investment, industrialization in the last two decades and globalization, dynamics and urban sociospatial attributes of post-socialist city in China changed. Salient features include: the space of globalization typified by the creation of urban high-tech and financial districts; the space of elitist consumption represented by glittering shopping centres, chain stores, supermarkets, luxurious hotels as well as numerous fancy restaurants. The rapid development of the urban tertiary sector which includes: hotels, restaurants, small shops and personal services creating numerous spaces of consumption for the ordinary urban residents. It also created inequalities in the form of spaces of differentiation and marginalization exemplified by the emergence of exclusive gated communities and dilapidated migrant enclaves.

There are four national political and socioeconomic attributes, which distinguish Chinese city from a capitalist city: 1) Persistence of a very strong party-state at the centre as well as local levels and its penetration into the market (Ma, 2002). Its dual roles in regulation and its participation in economic production, capital accumulation and urban development, is responsible for the outlook of many urban businesses and buildings. Chinese state is an ensemble of economic actors and government officials behave as entrepreneurs, corporate management teams, silent partners and investors in the private economy. The long arms and visible and invisible hands of the state, play an important role in China's urban restructuring (Walder, 1997). 2) The more investment of capital a city can attract, the more impressive its built environment becomes, and greater are the chances for the promotion of city leaders; making the cities "entrepreneurial" (Wu, 2003). City leaders actively promote their cities by creating privileged spaces of production and consumption for the investors and the rich. Image of the city is enhanced with the construction of signature buildings and other types of urban physical elements such as public squares, subways, etc. (Leaf, 1998). 3) Relaxation of rural-urban migration has led to massive flows of rural population to the cities, creating numerous migrant enclaves. Participation of migrant workers in urban job market with minimum income has a direct bearing on socio-spatial and economic inequalities and labour market segmentation ( $\mathrm{Gu}$ and Liu, 2002). 4) Strong inter-personal ties and networks built on the basis of kinship and origin have been instrumental not only in the formation of migrant enclaves but also in the emergence of informal institutions and non-state economic activities in urban China (Ma and Wu, 2005), (Tsai, 2002).

Migrant enclaves in post-socialist Chinese city, also known as "urbanizing villages" or "villages in the city", create a kind of social inequality in urban China. These villages are just like slums inhabited by the poor and unprivileged. These sub-standard urbanising villages are more affordable than the alternatives for low-income migrant workers. Housing massive numbers of rural migrants in any developing country is a challenging task for an urban government (Ma and $\mathrm{Wu}, 2005)$.

There are three main indicators of efficiency in China's urban labour markets; urban inequality, rural-urban migration and urban unemployment. Skills necessary for high productivity are relatively scarce in the early stages of development and thus those with skills are paid well. Enhanced technology substitutes for low-skilled labour which ultimately depressing the wages. It increases inequality but efficiency increases as well. During rural to urban migration labour moves from low-efficiency to high-efficiency locales which increases urban unemployment (Ma and $\mathrm{Wu}, 2005)$.

For instance in 1988, attracted by the free-market economy of Hainan, some 100, 000 migrants from the mainland flooded into this island; mostly fresh graduates and other qualified young people. Provincial 
government was swamped by more than 180, 000 applications for only 30, 000 jobs, with the result that those unable to find work turned to street hawking. Meanwhile, in-migrating peasant workers congregated in sprawling urban 'village' settlements, which lacked basic facilities. Infrastructure of urban centres sagged under these enormous pressures, resulting in an increase in crime rate in the urban life of the island (Kai and Geoffrey, 2007).

Untrammeled urbanization in many parts of China has produced serious challenges for urban planning, particularly manifested as massive land and property speculation, chaotic and illegal land development outside planning and development zone frameworks, and general degradation of the urban and economic environment. Lack of an explicit vision for the direction and magnitude of urban growth and spatial restructuring, creates this kind of vulnerabilities. City managers and planners in post-reform China need to invent practical approaches to cope with these situations, which are neither envisaged nor experienced in the socialist past (Yeh and Wu, 1999).

\section{Post-Socialist City; an Engine of Growth and regional inequality}

Since the early 1980s, China has relied on the city as the engine of growth to propel national economic development. A series of administrative changes, for instance annexation of suburban counties, have significantly enhanced the territorial power of cities (Ma, 2004). One of the most important decisions made by the central government that has fundamentally reconfigured China's post-socialist urban landscape is the policy of paid transfer of the right to use urban land, while leaving state ownership of urban land intact. Introduced in 1987, this policy allows to obtain the use right of a piece of urban land to be negotiated between a potential user (often a developer) and the current occupier (Samuel P et al, 2003). Persistent inequalities across regions are a feature of many developed and developing nations. This fact conflicts with standard neoclassical theory, which suggests that in a well-functioning economy, regional inequalities should be eliminated through factor mobility, trade, or arbitrage (Magrini, S, 2007).

China presents a unique and important opportunity to study regional inequality. In terms of income, China is a very unequal country. By the year 2000, China achieved highest rate of economic growth but also one of the highest degrees of rural-urban income inequality in the world (Yang, 2002), which is a relatively new phenomenon in post-socialist China. According to World Bank estimates, China's income Gini coefficient far exceeds that of South Asian countries such as India, Bangladesh and Pakistan. Income differences in China are large, both inter- and intra-regionally, with inter-regional differences increasing over time. China is also a country in transition, altering its institutions and economy at a rapid pace but with considerable variation across provinces (Christopher et al, 2009).

\section{Urban Spaces in Post Socialist City}

There are three types of urban spaces in the wake of on-going rapid urbanisation in China. The 'new' urban space reflects the expansion of China's cities, for example the Pudong New District, Shanghai, to accommodate numerous newly urbanised populations. Existing central cities are undergoing restructuring, driven by the new urban economy - hence the 'renewed' urban space. Those urban spaces that are not yet redeveloped are the 'ignored spaces' (Tingwei, 2002).

\section{Small vs. Large Post-Socialist City}

Since 1980's, China's current urban policy has still favoured the development of small cities. Many studies show that larger cities tend to have lower unemployment rates. There is a high positive correlation between city efficiency and city size, not only in economic but also in social and environmental terms. Small cities are at a disadvantage with respect to the provision of urban infrastructure. A certain consumption scale and a population size are necessary conditions for promoting service industries and markets. On the contrary even China's largest city, Shanghai for example, does not exert the kind of relative economic dominance in China as Tokyo, New York, London, Mexico City or Jakarta do over their respective national economies (Wan G et al, 2007).

\section{Post-Socialist Urbanization and Arable Land}

China is feeding $22 \%$ of the global population on less than $9 \%$ of the world's cultivated land. To feed its future theoretical peak population of 1.6 billion, China needs to have a minimum cultivated land area of 107 million ha. Coastal provinces of Southeast China like Jiangsu and Guangdong, witnessed grain output drops of nearly 30 million tons in 2003 from the 1998 level, due to loss of cultivated land to urbanization (Chen, 2007).

\section{Inefficient Post-Socialist Regional Development}

Since 1996, in addition to 25 national and provincial urban development zones $(301.74 \mathrm{~km} 2)-$ six industrial development, 14 tourism development and five comprehensive development zones - some 95 city- and county-level development zones $(488.21 \mathrm{~km} 2)$ have also been established by the government. Lack of domestic and foreign investment in these zones resulted in large insufficiently financed tracts of vacant land, pointing to inefficient planning and implementation (Kai and Geoffrey, 2007).

\section{Broad Categories of Regional Inequality in Post-Socialist China}

There are two broad categories of regional inequalities, which include: 1) persistent inequalities due to market imperfections associated with institutional or informational barriers that limit factor mobility, trade, or both 
(Magrini, 2007). Persistent regional disparities can be linked to institutional barriers such as quotas on flows of human and physical capital, tariffs, and insufficient property rights, and 2) regional inequalities in income as a result of unmeasured offsetting factors that work to equalize well-being across regional agents. These factors include differences in government tax and transfer programs, cost-of-living differences, and differences in amenities (Rice and Venables, 2003). Removal of the hukou system has positive contribution in regional as well as urban-rural inequality (Whalley and Zhang, 2004).

In one of the recent studies, Wan, Lu, and Chen (Wan G et al, 2007) observed that increasing globalization, uneven domestic capital accumulation, and privatization contribute to regional inequality in China, while the effects of location, urbanization, and the dependency ratio have been declining. There is divergence in Chinese provinces in terms of real per capita GDP. Discontinued provision of free education, housing, and medical care as well as growing uncertainty increased the incidence of urban poverty when measured in terms of expenditure (Meng X et al, 2005).

In one of the landmark studies carried out by Candelaria et al. (Christopher $\mathrm{C}$ et al, 2009), social and regional inequalities in China were investigated on provincial level. Cost-of-living differences were found as an important offsetting factor. Average nominal wages were adjusted by a province-specific consumer price index (CPI) to obtain average real wages. It was observed that cross-province migration to urban areas is driven, at least in part, by wage differentials; however, contrary to findings by Whalley and Zhang (Whalley and Zhang, 2004), migration does not reduce wage inequality across provinces. This is because between 1995 and 2000, a period for which migration was studied, there were still restrictions on labour mobility that precluded labour flows from having any noticeable effect in terms of equalizing wages across provinces (Christopher C et al, 2009).

From the beginning of the Mao era up to 1986, inequality across major regions - as measured by the coefficient of variation of per-capita real gross domestic product - trended downward, but it rose sharply in the decade of the 1990s. The gap between the coastal region and other regions has increased rapidly since 1991. The coast's early advantage over the interior and far west soared to a ratio of approximately 2.4 by 2003 . By comparison, among the major regions of the United States in 2004, the ratio of the highest to lowest regional per capita GDP was only 1.3 (http://www.bea.gov/). In China in the year 2003, the ratio of real per-capita GDP between the wealthiest province and the poorest was 8.65 , while in India for 2004, the comparable ratio (in nominal terms) was only 4.5 (Belton Fleisher et al, 2009) (Purfield Catriona 2006).

\section{Reasons of Persistent Inequality}

There are many offsetting factors for persistent inequality. Candelaria et al (Christopher et al, 2009) first considered education level. Due to unavailability of direct measure of labour quality, two different measures of education levels were used in the province to proxy for the quality of labour i.e. differences in labour quality and industry composition in the provinces. Because labour productivity may be higher in some industries, industry composition will affect the average wage in the province. While labour is expected to move to the industries that are more productive, structural changes in the economy take a long time to complete and thus inequality that is caused by industry composition is expected to be persistent. It is found that higher levels of education are associated with higher average real wages (Christopher et al, 2009).

\section{Urban Management Problems in Post-Socialist China}

Today large cities all over the world are facing problems like inadequate water supplies, poor sewerage, housing shortages, improper garbage disposal, scanty greenery, traffic congestion, high prices, environmental pollution, dehumanization, and so on. These problems are, in a sense, a condensation and ensuing eruption of the defects inherent in modern civilization. Obviously, city governments should be capable enough to solve these problems. Factors like economic globalization, the emergence of world-wide economic sectors and international institutions have changed to challenge traditional urban governments. Inter-urban competition has become fiercer, with cities trying hard to "sell" themselves for a number of investment and other reasons in what has been termed "place wars". In an increasingly competitive world, city governments have had to become more entrepreneurial. Government in China directly governs economic development because of political reasons, which brings extremely disadvantageous effect on the process of urbanization (Shujian, 2007).

\section{State and Urban Management}

Prior to the reform and opening, the Chinese state controlled almost all resource allocations such as capital and land. The presence of many new and outside factors in urban development - such as FDI, private investment, temporary resident and transient populations have created a very different and competitive environment, where urban planners must take on the new roles of facilitating and managing non-state projects, and mediating between different, often conflicting interests (Yeh and $\mathrm{Wu}, 1999$ ).

\section{Scale of Urbanization and Quality}

The process of urbanization also involves the improvement of urban quality including renewing the city, optimizing urban spatial organization and improving urban function. In China's process of urbanization, however, government only focuses on the increase of quantity and scale, rather than on the improvement of quality. 
Blindly seeking for the increase of population and the enlargement of urban size leads to not only wasting resources but also menacing the sustainable development of cities. The city development is lacking holistic characteristics, and serious and scientific planning. Each city makes and implements this big planning respectively, which leads to similar industry structure and overlapped infrastructure, and thus wastes resources. As a result, scholarship criticizes the big graphic projects fiercely. One of the most important lessons learnt from the distant and recent past is the failure of out-dated models and practices of physical planning as well as of isolated projects (Shujian, 2007).

\section{Conclusions}

Urban socio-spatial restructuring is an on-going process and cities are always incomplete. As such, the Chinese city (and perhaps cities in general) is best seen as "multiplex city" with "the co-presence of multiple spaces, multiple times and multiple webs of relations" (Amin and Graham, 1997) and with "an amalgam of often disjointed processes". In the last two decades, the Chinese city under transformation has developed new elements of market capitalism and neoliberalism, both spatial and socioeconomic, but it continues to be affected by path-dependent processes and elements left behind from state socialism and the more distant past. Meanwhile, the Chinese city also possesses certain forms commonly found in the developing world (such as crowded streets and migrant settlements). China's post-socialist urban landscape differs dramatically from that of the socialist era. Chinese city in the post-socialist age has witnessed the appearance of new urban elements as gated communities and malls.

Regional inequality in China has been persistent and even growing in the past two decades. Main reasons include structural and long-term factors such as labour quality, industrial composition, and geographical location. Regional income inequality in China is not likely to go away in the near future. Removing barriers to labour mobility will help reduce cross-province wage inequality, but urban infrastructure is unable to accommodate large inflows of new migrants. That is why regional inequality in China is expected to persist for quite some time.

Since the launch of economic reforms in 1978, which emphasizes decentralization, marketization, and globalization, consequently global and local factors emerged as major forces shaping China's regional inequalities and urban management problems. Prior to the reforms, the Chinese government had controlled almost all resource allocations such as capital and land. It has created a very different and competitive environment, where urban planners must take on the new roles of facilitating and managing non-state projects, and mediating between different, often conflicting interests.

In the wake of these challenges the urban management needs to take proper and timely measures with regional, national and global perspectives. The process of urbanization in the future needs to be thought of differently from how we considered urbanization in the past. It goes well beyond the urban engineering paradigm in city making. It is necessary to rethink priorities, requiring an understanding of the nature of urban trends, their paradoxes and contradictions, if solutions for tomorrow's world rather than yesterday's are to be found.

\section{References}

Abramson D. (2006). Urban Planning in China: Continuity and Change: What the future holds may surprise you. Journal of the American Planning Association 72(2): 197-215.

Amin A and Graham S. (1997). The ordinary city. Transactions of the institute of British Geographers, New Series, 22: 411-29.

Belton Fleisher, Haizheng Li, Min Qiang Zhao. (2009). Human capital, economic growth, and regional inequality in China. Journal of Development Economics. doi:10.1016/j.jdeveco.2009.01.010.

Brockherhoff M P. (2000). An urbanizing world. Population Bulletin 55 (3): 3-44.

Chen J. (2007). Rapid urbanization in China: A real challenge to soil protection and food security. Catena 69: $\mathrm{p}$. $1-15$.

Christopher C, Daly M and Hale G. (2009). Beyond Kuznets: Persistent Regional Inequality in China. Federal Reserve Bank of San Francisco, Working Paper Series.

Gu C L and Liu H Y. (2002). "Social polarization and segregation in Beijing" in Logan J R (ed.) The New Chinese City. Oxford; Blackwell: p. 198-121.

Kai GU and Geoffrey Wall. (2007). Rapid urbanization in a transitional economy in China: The case of Hainan Island. Singapore Journal of Tropical Geography. 28: 158-170.

Leaf M. (1998). Urban planning and urban reality under Chinese economic reforms. Journal of Planning Education and Research. 18: 145-153.

$\mathrm{Ma}$ and Wu. (2005). Restructuring the Chinese city: changing society, economy and space. London, UK, Routledge: p. 21-38.

Ma L J C. (2004). China's changing urban administrative system: spatial restructuring and local economic development. Forthcoming in Political Geography. 
Ma L. J. C. (2002). Urban transformation in China, 1949-2000: a review and research agenda. Environment and Planning A, 34(9): 1545-1570.

Magrini S. (2007). Regional (di) convergence," in Handbook of Regional and Urban Economics, vol. 4, pp. 2741-2796. Elsevier B.V.

Meng X, R Gregory and Y Want. (2005). Poverty, inequality, and growth in urban China, 1986-2000," Journal of Comparative Economics. 33(4): 710-729.

Purfield Catriona. (2006). Mind the gap-Is economic growth in India leaving some states behind? IMF Working Paper WP/06/103. International Monetary Fund, Washington, D.C.

Rice P and A Venables. (2003). Equilibrium regional disparities: Theory and British evidence," Regional Studies, Vol 37 , pp 675-686.

Samuel P.S. Ho and George C.S. Lin. (2003). Emerging Land Markets in Rural and Urban China: Policies and Practices. The China Quarterly, 175, pp 681-707 doi:10.1017/S0305741003000407 17.

Shujian Wang. (2007). Characteristics of Urbanization in China. Asian Social Science. Vol. 3, No. 9, pp pp 97-99.

Tingwei Zhang. (2002). Urban Development and a Socialist Pro-Growth Coalition in Shanghai. Urban Affairs Review, Vol. 37(4): 475-499.

Tsai K S. (2002). Back-Alley banking: private entrepreneurs in China, Ithaca: Cornell University Press.

United Nations. (2004). World Urbanization Prospects (the 2003 revision). Population Division, Department of Economic and Social Affairs, United Nations, New York.

United States Bureau of Economic Analysis. http://www.bea.gov/

Walder A G. (1997). "The state as an ensemble of economic actors: some inference from China's trajectory of chang", in Nelson, J. M. et al. (eds.), Transforming post-Communist political economy, Washington, DC: National Academy Pres: p. 432-452.

Wan G, M Lu and Z Chen. (2007). Globalization and Regional Income Inequality: Empirical Evidence from within China," The Review of Income and Wealth 53(1): 35-59.

Whalley J and S Zhang. (2004). Inequality Change in China and (Hukou) Labor Mobility Restrictions," NBER Working Paper 10683.

Wu F L. (2003). The (post-) socialist enterpreneurial city as a state project: Shanghai's reglobalisation in question. Urban Studies 40(9): 1673-1698.

Yang Dennis Tao. (2002). What has caused regional inequality in China? China Economic Review 13: 331-334.

Yeh A G O, Wu F. (1999). The transformation of the urban planning system in China from a centrally planned to transitional economy. Progress in Planning 51(3): 167-252. 